\title{
Impacts of Human Resource Practices on Employee's Perceived Performance: A Study of Private Schools Faculty of Pakistan
}

\author{
Awais Ahmad (leading author) \\ University of Narowal, Punjab, Pakistan \\ Khadija Pervaiz, \\ BBA Program, University of Narowal, Punjab, Pakistan \\ Sehar Fatima, \\ BBA Program, University of Narowal, Punjab, Pakistan \\ Moaz Ahmad \\ BBA Program, University of Narowal, Punjab, Pakistan
}

Received: May 12, 2019 Accepted: May 30, 2019 Online published: June 4, 2019

doi:10.5296/ijhrs.v9i2.14890 URL: https://doi.org/10.5296/ijhrs.v9i2.14890

\begin{abstract}
The current research study determined the result of four human resources practices -compensation, promotion, performance evaluation, and grooming and maturation along the employee perceived performance of private schools of Pakistan. 101 research studies supported our Hypothesis that HR practices have a confident relationship with employee's perceived performance. The outcomes of this research also demonstrated a significant positive relationship of HR practices with employee's perceived performance.
\end{abstract}

Keywords: HR practices, compensation, promotion, performance evaluation, training and development, employee perceived performance

\section{Introduction}

Human resources management defined as a strategy and logical approach by Armstrong 
(1995), he also signifies that employees are the valuable assets of every organization individually and collectively. Many research studies elaborate the measurable impact of HR practices on employee's perceived performance and that were directly related to the organizational productivity. Many researches have been conducted to determine the impact of HR practices on the employee's performance; HR practices impact positively to employee perceived performance (Hashim and Sarfaraz, 2017; Becker and Theselid, 1998). Many researchers concluded significant positive relationship between HR practices and employees perceived performance (Saira Hassan, 2016; Zulfaqar and Bilal, 2011).

Many researchers have been directing research on the relationship of HR practices and employee perceived performance, but these researchers were limited to developed nations. Pakistan is a growing nation and research phenomena is emerging and human resource department is showing in many establishments. This query were conducted on private school employees to detect out the impaction of Human Resource practices on employee's perceived performance. Much research has been conducted on university employees, but the literacy rate is low in Pakistan and there is a large turn of individual schools that provide the basis of the teaching system so this inquiry has been conducted to examine the performance of individual school employees and also how HR practices like (Compensation, promotion, performance rating, and grooming and development impact their perceived performance.

The main purpose of conducting research on private schools is that Human resource management system was considered as needed system for quality work and performance. It is also important to compete in the competitive environment. For quality work and performance enhancement the organizations use compensation to motivate them and get their employee's loyalties, evaluate their employee's performance to keep check on their employee has and promote them according to their performances and give them trainings as needed for current work and development system for their future need.

\section{Problem Statement}

Private schools have a big contribution in the development of effective education organization and the best performance of any system is dependent on its employee's effective and effective study. For a better performance, HR department is considered significant. It is believed that the presence of effective compensation, promotion, training and development and performance evaluation system gives good results and enhances the performance of employees.

Researchers have been conducted many researches on university employees, bank employees and many other multinational firms, this is the one of the basic nature research that is being conducted on private school employees to access the impact of four HR practices (Compensation practice, Promotion practice, Performance evaluation, and training and development). The study accessed the relationship of these HR practices on the employee perceived performance of private school employees of Pakistan.

\section{Objectives}

To assess the effect of promotion practices on employee perceived performance. 
To determine the effect of compensation practices on employee perceived performance.

To check the relationship between training and development and employee perceived performance.

To identify the impact of performance evaluation of employee perceived performance

\section{Research question}

How HR practices impacting employee's performance of private school employees of Pakistan?

\section{Literature Review}

\section{Human Resource Practices}

HRM practices are a process of attracting, motivating, and retaining employees to ensure the survival of the organization (Schuler and Jackson, 1987).HR practices play the role of mediator between organization's rules (Dessler, 2009). Many researcher have proven that HR practices have a significant and positive relationship with employee performance( Delery and Doty, 1996; Qureshi et al., 2006). The HR practices and employee perceived performance has positive and significant relationship (Zulfiqar and Bilal, 2011).HR practices shows a significant impact on the employee performance (Taibu and Nura, 2013). The study revealed a positive rich relationship between HR practices and employee performance (Saira Hassan, 2016).

\section{Perceived performance}

According to Spearman "Employee's Perceived Performance and HR practices have significant positive relationship with eachother". Employee performance is largely influenced positively by HR practices (Hashim and Sarfaraz, 2017). Performance of many organizations completely relies on the performance of their employees. Effective HR practices enhance the performance of organization and become reason of large profits (Datta et al., 2003). Employee performance is an aggregated value to an organization that employees participate to organizational purpose (Borman \& Motowidlo, 1993).

\section{Compensation Practice}

Compensation is anything that is given to an employee as a reward or return for his ther services or capabilities. Compensation practices have a significant direct relationship with an employee's performance (Hashim and Sarfaraz, 2017). Reward and compensation systems are important HR practices that contribute to performance of individuals and organization (Carrier, 1994).Employees are motivated when they are financially returned, it enhances to their performance (Caruth and Handlogten, 2001). There is positive correlation present between employee performance and compensation practices (Singh, 2004). There is positive relationship of reward policies with the employee performance (Shehzad et al. 2008). Maintenance and establishment an effective compensation system is an important task for the organization (Durbin, 2008). The relationship of compensation system and employee's performance leads to an overall performance of organization, so employees should be given 
incentives, rewards and benefits to encourage them for the betterment of their performance.

H1: Compensation practices have significant on employees perceived performance.

\section{Performance Evaluation Practice}

Performance Evaluation has a significant relationship with employee's perceived performance (Hashim and Sarfaraz, 2017.The performance assessment or evaluation is a systematic expression of strength and weakness of employees (Mello, 2005).employee perceived performance and performance evaluation have a rich relationship (Baloch et al., 2010). A strong relationship exists between performance evaluation practice and employee's perceived performance (Taseema and Soeters, 2006).

H2: Performance evaluation shows positive impact on employee perceived performance.

\section{Promotion Practice}

Promotion practice has a direct relationship with employee performance (Hashim and Sarfaraz, 2017). There is positive association between promotion practice and employee performance (Shehzad, 2008). There is a positive relationship between promotion practice and employee's performance ( Taseema and Soeters, 2006). Promotion is important in enhancing the performance of individual employees (Guest, 2002). Promotion practice showed a positive relationship with employee's perceived performance (Zuilfqar and Bilal, 2011).

H3: Promotion practice has a positive impact on employee perceived performance.

\section{Training and Development}

Training is one of important HR activities in the organization and ensures to achieve the goals of any organization. It is important to understand the training and development in the betterment of any organization and enhancement of the performance of employees. Training is an organized task of information, skills, and attitudes lead to enhancing performance in a particular situation (Grossman and Salas, 2011). Proper training programs should design and implement to achieve tasks (Dessler, 2009). Training and development are designed to improve employee performance; competency levels and that enhance the organizational performance. Every organization tries to compete in the global economy on the basis of skills knowledge; and motivation of their employees and it must realize the impact of Training and development on employee performance (Aguinis and Kraiger, 2009). Training is different from development, training is to fulfill the present requirements for a job and development is to fulfill the requirements of future (Armstrong, 2009). Training improves the skill level of employees for a specific objective while development is important for long time learning (1971).

H4: Training and development have direct and positive relationship with employee perceived performance. 


\section{Macrothink}

\section{Methodology}

\section{Data Collection Technique}

For this research data collected through a self prepared questionnaire. This questionnaire is taken from the study of (Hashim and Sarfaraz, 2017), which is the study of previously researched of Shehzad et al. (2008) that measures the HR practices compensation, performance evaluation, promotion practices used to determine the employee performance. But in this research a new HR practices is adding training and development. Questionnaire for training and development adopted from the research study of Nancy Quansah, 2013. The reason behind the selection of new variable was that it is best practice of HR that effect the employee performance. The questionnaire that is being used in the current study is same as previous study because the nature of study is same.

The first portion of questionnaire is regarding demographics composed of two items. The next part about employee performance which is dependent variable having 4 questions. The 2nd part is compensation practice that was the first independent variable, it consisting of 6 questions that gave clear idea about distinct idea of HR practice. Similarly the 3rd portion is about performance evaluation that is 2 nd independent variable and has 6 questions. The 4th part of questionnaire consists of 3 questions related to promotion practice. The 5 th part of the questionnaire was about training and development has 6 questions that were provided the idea about this practice to the respondent.

For getting the response five point liker scale was used. According to the finding alpha value of $\mathrm{EP}$ is $.803, \mathrm{CP}$ is $.845, \mathrm{PE}$ is .743, $\mathrm{PP}$ is .684 and TD is .833 for the response in the liker scale 1 point is strongly disagree, 2 shows disagree, 3 neutral , 4 point show agrees and 5 is strongly agree.

Target sector

The target sector of this research is private school teachers.

Target population

Target population for this research is 250 staff members; male and female of the main leading schools was selected for conducting the response.

Sample size and technique

For gating the primary data researcher used connivance sampling technique. Although this is restricted to school of on refer schools. Total 230 questionnaires were distributed among the schools. 10 facility members were taken as sample size from every school. From 230 questionnaires 200 were returned and 30 were misplaced or not accurately responded. The response of the respondent was $80 \%$ which is enough for current study. 
Model of research

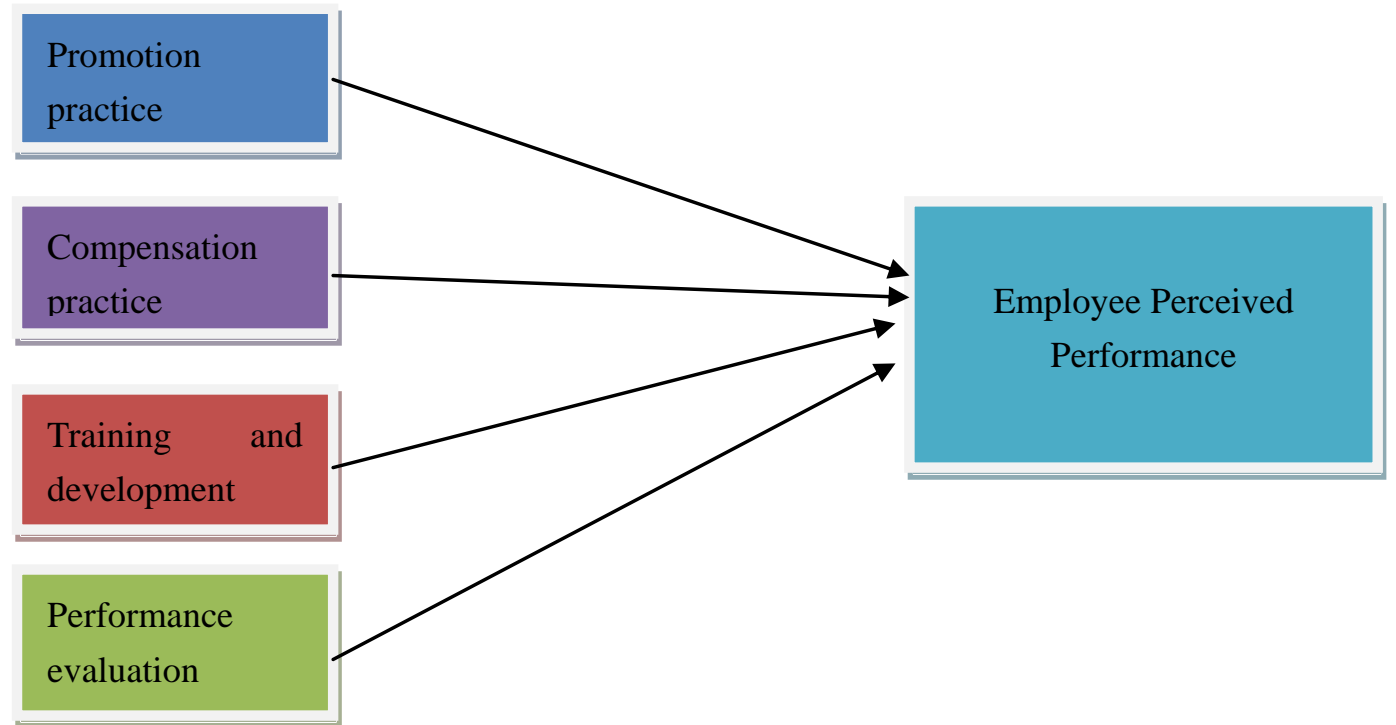

Figure 1. Research Framework

Table 1. Frequencies and percentile of the demographic assessment

\begin{tabular}{|l|l|c|c|}
\hline & Description & Frequency & Percentage \\
\hline \multirow{3}{*}{ GENDER } & & & \\
& Male & 84 & 33.6 \\
& Female & 116 & 46.4 \\
QUALIFICATION & & & \\
& BA B.com & 40 & 20 \\
& B.ed & 20 & 10 \\
& Master & 100 & 50 \\
& M.phil & 40 & 20 \\
\hline
\end{tabular}

In this study demographic not used to calculate their relationship with employee performance. For the better understanding of response of the respondent we show a table consisting the respondent 84 male and 116 female (33.6\% male and $46.4 \%$ female). The education of majority was Masters (50\%), BAIB.Com 20\%, B.ed 10\% and M.Phil $20 \%$. 
Table 2. Correlation results of HR Practices and Employee's perceived Performance

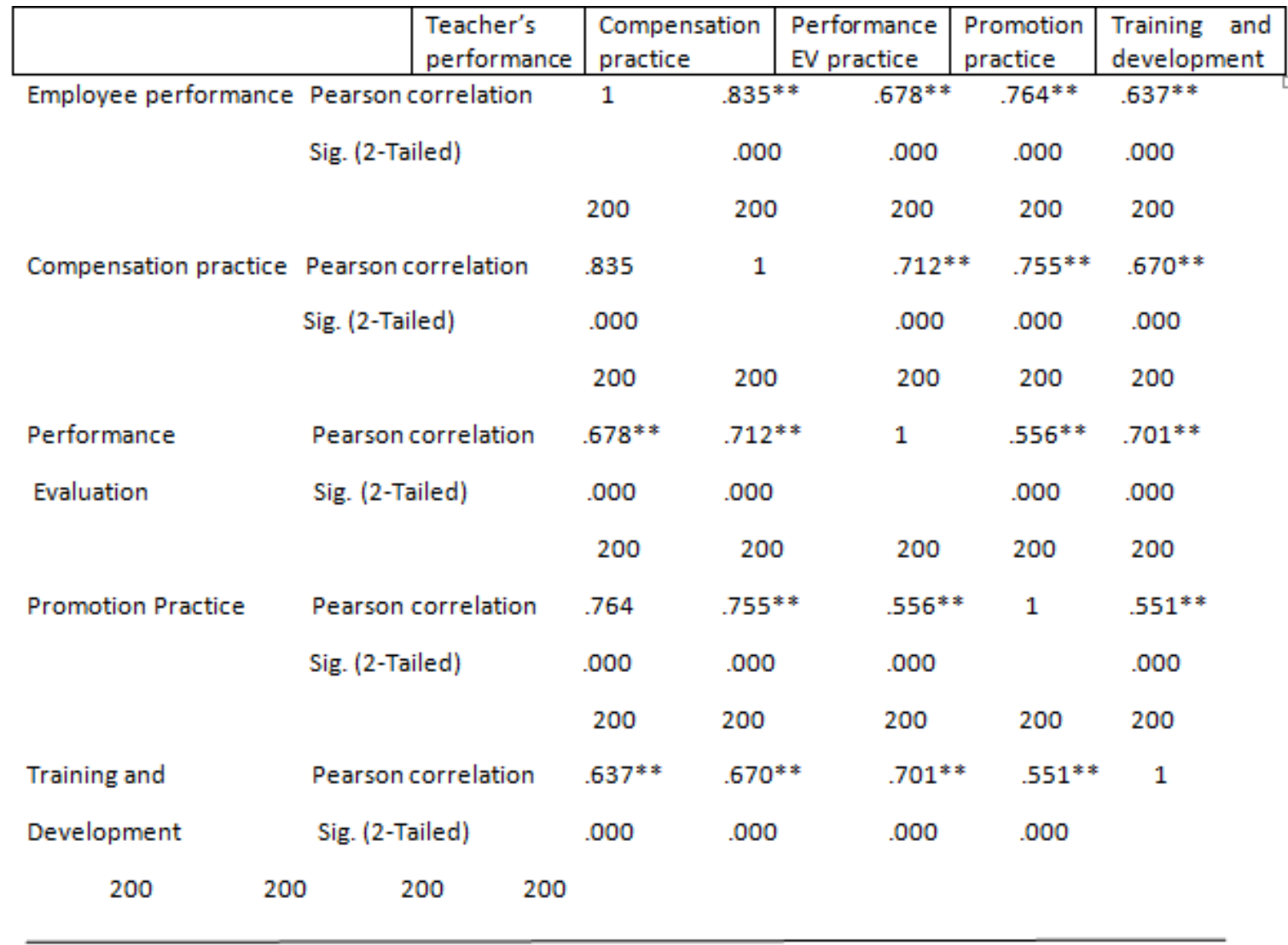

Correlation result is significant at the 0.01 level (2- Tailed)

Table 3. Regression Analysis for HR Practices and Employee's perceived performance

\begin{tabular}{|c|c|c|c|c|c|}
\hline Model & $B$ & S.E. & Beta & $\mathrm{T}$ & Sig. \\
\hline Constant & -.728 & .217 & & -3.354 & .001 \\
\hline Compensation Practice & .598 & .083 & .475 & 7.190 & .000 \\
\hline Performance Evaluation & .204 & .089 & .129 & 2.304 & .022 \\
\hline Promotion Practice & .352 & .064 & .298 & 5.468 & .000 \\
\hline Training and Development & .214 & .099 & .139 & 2.314 & .029 \\
\hline \multicolumn{6}{|l|}{$R 2=.753$} \\
\hline Sig. $F=0.000$ & & & & & \\
\hline
\end{tabular}

By using the regression analysis researcher examine the impaction of Human resources practices on employee performance. The value of $\mathrm{R}$ shows that the change in employee performance considered by Human Resource practices ( i.e. compensation practices $(\mathrm{B}=.598$, beta $=.475, \mathrm{~S} . \mathrm{E}=.83, \mathrm{t}=7.190, \mathrm{p}<.000)$ ( i.e. performance evaluation ( $\mathrm{B}$ 
$=.204$, beta $=.129, \mathrm{t}=2.304, \mathrm{p}<.022$ ) ( i.e. promotion practices $(\mathrm{B}=.352$, beta $=.298, \mathrm{t}=5.468$ and $\mathrm{p}<.000)$ ( i.e. Preparation and development $(\mathrm{B}=.214$, beta $=.139, \mathrm{t}=2.314, \mathrm{p}<.029)$. Where the board shows that HR practices (compensation, performance rating, promotion practices and training and development) have a significant and positive relationship with employee performance.

\section{Data Analysis and Discussion}

The results of this research showed that HR practices have a significant positive impact on the employee's performance. SPSS software is used for this purpose. The relationship shown in the table is between four independent variables i.e. CP, PE, PP, and TD with employee's performance. The size of the total sample is 230 to find this relationship. To check the relationship between these variables Pearson correlation test and regression were used. The test indicates that compensation practice with .83 values is strongly and positively correlated with employee's performance in private schools of Pakistan. Previous studies of Hashim and Sarfaraz (2017) supported this; their finding was (.47) which shows compensation practice has impact on private employee's performance. The p-value between the two is 0.000 , which at $5 \%$ significance level shows there is significant relation between employee's performance and compensation practice.

In PE with .67 values shows positive relationship with employee's performance. This result is supported by the previous study of Hashim and Sarfaraz (2017) with value (.38), also p-value 0.000 , at $5 \%$ significance level, that shows the significance relation between EP and PE.

Promotion practice with (.76) value also shows a strong relationship with employee's performance this result is also supported by the previous study of Hashim and Sarfaraz (2017) with value (.44), similar here the p-value is 0.000 at $5 \%$ significance level and shows significant relationship between EP and PP.

The last independent variable training and development with value (.63) shows a strong relationship with employee's performance, the p-value is 0.000 at $5 \%$ significance level shows a significant relationship.

\section{Conclusion}

The purpose of the study was to find the relationship between HR practices and employee perceived performance of private school employees. From the current results it is concluded that the independent variables that are compensation, promotion, employee evaluation, and training and development have a positive and significant relationship with employee's perceived performance of private school employees. The data is supported by the secondary data retrieved from literature, so hypothesis of the study is accepted.

H1: Compensation practices have significant on employees perceived performance.

H2: Performance evaluation shows positive impact on employee perceived performance.

H3: Promotion practices have a positive impact on employee perceived performance.

H4: Training and development have direct and positive relationship with employee perceived 
performance.

It shows that if Human Resource practices are well implemented with better reward or returns the performance of employees can be increased, also check on the employee's performance gives measureable results and training and development is very effective in employee's better performance.

\section{Research Implications}

We experienced a direct relationship of Human Resource practices and employee's perceived performance. It is assured that HR practices provide a good mechanism that leads to improve performance. Our research also indicates that private employees are more concerned with the promotion. It is also important because it shows the expression of motivation that leads to performance improvement. HR practices have a positive impact especially on private employees. It is suggested that HR practices should be implemented properly for better performance of employees. It shows good results on private school employees such practices should also implement on Public sector schools.

\section{Suggestion for Future Research}

This research is conducted in private schools; in future, such research should conduct on public sector schools and also in other sectors. The sample size can be increased with the same variables.

\section{References}

Aguinis, H., \& Kraiger, K. (2009). Benefits of training and development for individuals and teams, organizations, and society. Annual Review of psychology, 60, 451-474. https://doi.org/10.1146/annurev.psych.60.110707.163505

Armstronge, M. (2009). Armstrong's handbook of human resources management practice (11th ed.). Pakistan. Pakistan Economic and social Review, 47(2), 269-292.

Borman, W. C., \& Motowidlo, S. M. (1993). Expanding the criterion domain to include element of contextual performance. Personnel Selection in Organizations; San Francisco: Jossey-Bass, 71.

Bowra, A. Z, Sharif, B., Saeed, A., \& Niazi, K. M. (2011). Impact of HR practices on employee performance in banking sector of Pakistan.

Carrier, C. (1994), Interpreneurship in large firms and SMEs: A comparative study. International Small Business Journal, $12(3), \quad$ 54-61. https://doi.org/10.1177/0266242694123005

Caruth, D. L., \& Handlogten, G. D. (2001). Managing compensation and understanding it too: A handbook for the perplexed. Green Wood Publishing Group.

Datta, D. K., Guthrie, J. P., \& Wright, P. M. (2003). HRM and productivity: Does industry matter. 


\section{Macrothink}

International Journal of Human Resource Studies ISSN 2162-3058 2019, Vol. 9, No. 2

Delery, J. E., \& Doty, D. H. (1996). Modes of theorizing in strategic human resources management: Tests of Universalistic, contingency and configurational performance predictions. Acad. Manage. J., 39(4), 802-835. https://doi.org/10.5465/256713

Dessler, G. (2009). A framework for human Resource Management. Pearson Education India.

Durbin, J. (2008). Essentials of Management. 8th ed. New York: Cengage Learning.

Grossman, R., \& Salas, E. (2011), The transfer of training: What really matters. International Journal of Training and development, 15(2), 103-120. https://doi.org/10.1111/j.1468-2419.2011.00373.x

Guest, D. (2002). Human Resource management, corporate performance, and employee well-being: building the worker into HRM. The Journal of Industrial Relations, 44(3), 335-358. https://doi.org/10.1111/1472-9296.00053

Hashim, M., \& Rafi, S. (2017). Impact of Human Resource Practices on employee perceived performance: A study of teaching faculty in private universities of Peshawer, Pakistan. City university research Journal, Malaysia.

Hassan, S. (2016). Impacts of HRM on employee performance. https://doi.org/10.6007/IJARAFMS/v6-i1/1951

Huselid, M. A. (1995). The impact of Human Resource management practices on turnover, productivity and corporate financial performance. Acad. Manage. J., 38(3), 635-672. https://doi.org/10.2307/256741

Jackson, S. E., \& Schuler, R. S. (2000). Managing Human Resources; A partnership Perspective,Ohio, South-Western College Publishing.

Mello, J. A. (2005). Strategic Human Resource Management (2nd ed.). South-Western college.

Qureshi, T. M., Ramay, M. I., \& Marwat, Z. A. (2006). Impacts of human resource management practices on organizational performance in Pakistan.

Shehzad, K., Bashir, S., \& Ramay, M. I. (2008). Impact of HR practices on perceived performance of university teachers in Pakistan. Int. Rev. Bus. 4(2).

Singh, K. (2004). Impact of HR practices on perceived firm performance in India. Asia Pac. J. Hum. Res., 42(3), 301-317. https://doi.org/10.1177/1038411104048170

Taibu, A., \& Nura, A. A. (2013). Assessing the effects of Human Resource management(HRM) practices on employee job perfoemance: A Study of Usmanu Danfodiyo Univerdity Sokoto. Journal of Business studies Querterlty, 5(2), 247-259.

Taseema, M. T., \& Soetters, J. L. (2006). Challenges and practices of HRM in developing countries:testing the HRM-performance link in the Eritrean civil service. Int. J. hum. res., 17(1), 86-105. https://doi.org/10.1080/09585190500366532 


\section{Copyright Disclaimer}

Copyright for this article is retained by the author(s), with first publication rights granted to the journal.

This is an open-access article distributed under the terms and conditions of the Creative Commons Attribution license (http://creativecommons.org/licenses/by/4.0/). 